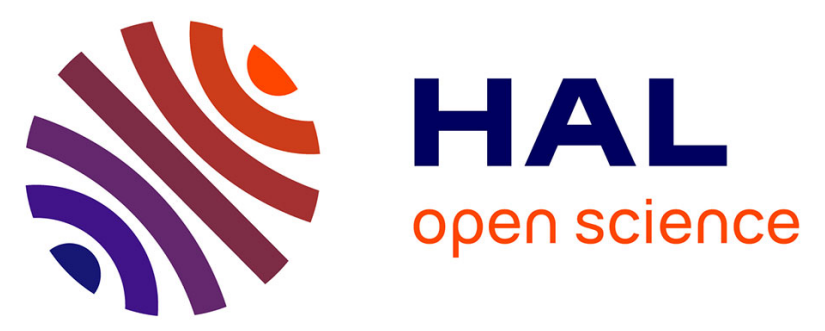

\title{
Antibacterial activity of some natural products against bacteria expressing a multidrug-resistant phenotype
}

\author{
V. Kuete, S. Alibert-Franco, K.O. Eyong, B. Ngameni, G.N. Folefoc, J.R.
} Nguemeving, J.G. Tangmouo, G.W. Fotso, J. Komguem, B.M.W. Ouahouo, et al.

\section{To cite this version:}

V. Kuete, S. Alibert-Franco, K.O. Eyong, B. Ngameni, G.N. Folefoc, et al.. Antibacterial activity of some natural products against bacteria expressing a multidrug-resistant phenotype. International Journal of Antimicrobial Agents, 2011, 37 (2), pp.156. 10.1016/j.ijantimicag.2010.10.020 . hal00659899

\section{HAL Id: hal-00659899 https://hal.science/hal-00659899}

Submitted on 14 Jan 2012

HAL is a multi-disciplinary open access archive for the deposit and dissemination of scientific research documents, whether they are published or not. The documents may come from teaching and research institutions in France or abroad, or from public or private research centers.
L'archive ouverte pluridisciplinaire HAL, est destinée au dépôt et à la diffusion de documents scientifiques de niveau recherche, publiés ou non, émanant des établissements d'enseignement et de recherche français ou étrangers, des laboratoires publics ou privés. 


\section{Accepted Manuscript}

Title: Antibacterial activity of some natural products against bacteria expressing a multidrug-resistant phenotype

Authors: V. Kuete, S. Alibert-Franco, K.O. Eyong, B.

Ngameni, G.N. Folefoc, J.R. Nguemeving, J.G. Tangmouo, G.W. Fotso, J. Komguem, B.M.W. Ouahouo, J.-M. Bolla, J.

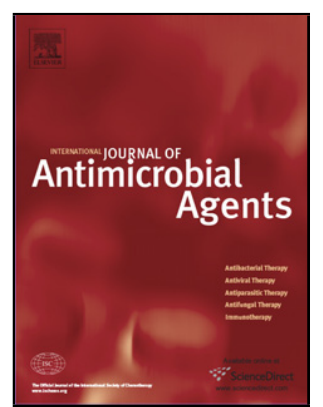
Chevalier, B.T. Ngadjui, A.E. Nkengfack, J.-M. Pagès

PII:

DOI:

Reference:

S0924-8579(10)00493-0

ANTAGE 3474

To appear in: International Journal of Antimicrobial Agents

Received date: $\quad$ 1-6-2010

Revised date: $\quad 13-10-2010$

Accepted date: $\quad 14-10-2010$

Please cite this article as: Kuete V, Alibert-Franco S, Eyong KO, Ngameni B, Folefoc GN, Nguemeving JR, Tangmouo JG, Fotso GW, Komguem J, Ouahouo BMW, Bolla J-M, Chevalier J, Ngadjui BT, Nkengfack AE, Pagès JM, Antibacterial activity of some natural products against bacteria expressing a multidrug-resistant phenotype, International Journal of Antimicrobial Agents (2010), doi:10.1016/j.ijantimicag.2010.10.020

This is a PDF file of an unedited manuscript that has been accepted for publication. As a service to our customers we are providing this early version of the manuscript. The manuscript will undergo copyediting, typesetting, and review of the resulting proof before it is published in its final form. Please note that during the production process errors may be discovered which could affect the content, and all legal disclaimers that apply to the journal pertain. 


\section{Antibacterial activity of some natural products against bacteria expressing a multidrug-resistant phenotype}

V. Kuete ${ }^{a, b}$, S. Alibert-Franco ${ }^{b}$, K.O. Eyong ${ }^{c}$, B. Ngameni ${ }^{d}$, G.N. Folefoc ${ }^{c}$, J.R.

Nguemeving ${ }^{\text {c}}$, J.G. Tangmouo ${ }^{\text {c }}$, G.W. Fotso ${ }^{\text {c }}$, J. Komguem ${ }^{\text {c }}$, B.M.W. Ouahouo ${ }^{\text {c }}$, J.-

M. Bolla ${ }^{b}$, J. Chevalier ${ }^{b}$, B.T. Ngadjui ${ }^{\text {c,d }}$, A.E. Nkengfack ${ }^{c}$, J.-M. Pagès ${ }^{b, *}$

${ }^{a}$ Department of Biochemistry, Faculty of Science, University of Dschang, P.O. Box 67, Dschang, Cameroon

b Transporteurs Membranaires, Chimiorésistance et Drug Design, UMR-MD1, IFR 88, UFRs de Médecine et de Pharmacie, Marseille, France

${ }^{\mathrm{c}}$ Department of Organic Chemistry, Faculty of Science, University of Yaoundé I, P.O. Box 812, Yaoundé, Cameroon

${ }^{d}$ Department of Pharmacy and Traditional Pharmacopoeia, Faculty of Medicine and Biomedical Science, University of Yaoundé I, P.O. Box. 8664, Yaoundé, Cameroon

ARTICLE INFO

Article history:

Received 1 June 2010

Accepted 14 October 2010

Keywords:

Terpenoids

Alkaloids

Phenolics 
Multidrug resistance

Efflux pump inhibitor

Antibacterial activities

* Corresponding author. Present address: Transporteurs Membranaires,

Chimiorésistance et Drug Design, UMR-MD1, IFR 88, UFR de Médecine, 27 Bd.

Jean Moulin, 13385 Marseille Cedex 05, France. Tel.: +33 4913245 87; fax: +33 4

91324606.

E-mail address: jean-marie.pages@univmed.fr (J.-M. Pagès). 


\section{ABSTRACT}

The present study assessed the antimicrobial activities of various natural products belonging to the terpenoids, alkaloids and phenolics against a collection of Gramnegative multidrug-resistant (MDR) bacteria. The results demonstrated that most of the compounds were extruded by bacterial efflux pumps. In the presence of the efflux pump inhibitor phenylalanine arginine $\beta$-naphthylamide (PA $\beta N)$, the activities of laurentixanthone B (xanthone), plumbagin (naphthoquinone), 4-hydroxylonchocarpin (flavonoid) and MAB3 (coumarin) increased significantly against all studied MDR bacteria. Laurentixanthone B, 4-hydroxylonchocarpin and MAB3 contained the same pharmacophoric moiety as plumbagin. This study indicates that the AcrAB-TolC (Enterobacteriaceae) and MexAB-OprM (Pseudomonas aeruginosa) efflux pumps are involved in resistance of Gram-negative bacteria to most of the natural products. 


\section{Introduction}

Multidrug resistance is a worrying cause of treatment failure in bacterial infections [13]. Various widely used antibiotics favour the selection of bacteria resistant to multiple antibacterial agents [4]. The expression of mutated genes, coding for resistance to a single drug (e.g. mutation in a target) or a specific resistance mechanism (e.g. enzymatic barrier), in association with the modulation of multidrug efflux pump or porin expression involved in transport, are the most common processes described in multidrug-resistant (MDR) bacteria [4-6]. A numbers of chemicals, such as phenylalanine arginine $\beta$-naphthylamide $(\mathrm{PA} \beta \mathrm{N})$ and 1-(1-naphthylmethyl)piperazine, quinoline derivatives, etc. [7], as well as natural products [8] have been found to inhibit bacterial efflux pumps. In addition, several natural compounds and integral components belonging to the usual pharmaceutical library have been tested to combat resistant bacteria $[9,10]$. The aim of the present work was to determine the antibacterial activities and potencies of several molecules, including terpenoids, alkaloids and phenolic compounds, against different bacterial strains expressing a MDR phenotype. The role of efflux pumps was investigated using pump-deleted strains and the efflux pump inhibitor (EPI) PA $\beta N$. Furthermore, this study aimed to determine the pharmacophoric group present in the active compounds.

\section{Material and methods}

\subsection{Chemicals for antimicrobial assays}

Chloramphenicol (Sigma-Aldrich, St-Quentin-Fallavier, France) was used as a reference antibiotic molecule. $p$-lodonitrotetrazolium chloride (INT) and PA $\beta N$ were 
used as a microbial growth indicator and EPI, respectively. Natural products (Fig. 1) were obtained from the chemical bank of the Laboratory of Organic Chemistry, University of Yaoundé I, Cameroon. Isolation and identification of the following compounds have been reported previously [10-13]: crotozambefurans A, B and C; bartericin C; MAB3; mammeisin; norcassaide; norerythrosuaveolide; 1,8-dihydroxy-6methoxy-3-methylanthraquinone; 3-geranyloxy-6-methyl-1,8-dihydroxyanthraquinone; vismiaquinone and vismiaquinone $\mathrm{C}$; bivismiaquinone; laurentixanthone $\mathrm{B}$; kaempferol; lapachol; 2-acetylfuro-1,4-naphathoquinone; newbouldiaquinone and newbouldiaquinone A; hardwickiic acid; 3-friedelanone; betulinic acid; oleanolic acid; 7-methoxycoumarin; 7-hydroxycoumarin; 1,5-dihydroxyxanthone; smeathxanthone A and smeathxanthone B; gancaonin Q; stipulin; angusticornin B; 1,7dihydroxyxanthone; 4-hydroxylonchocarpin; and quercetin.

\subsection{Bacterial strains and culture media}

MDR isolates and reference strains of Escherichia coli, Enterobacter aerogenes, Pseudomonas aeruginosa and Klebsiella pneumoniae are summarised in Table 1. Isolates were conserved at $4^{\circ} \mathrm{C}$ and were grown on Mueller-Hinton agar for $24 \mathrm{~h}$ before minimal inhibitory concentration (MIC) testing. Mueller-Hinton broth (MHB) was used for the susceptibility tests [20].

\subsection{Determination of bacterial susceptibility}

The respective MICs of the various compounds against the bacteria were determined using a rapid XTT colorimetric assay [14]. Briefly, samples were first dissolved in dimethyl sulphoxide (DMSO)/MHB. The solution obtained was then added to MHB 
and was sequentially diluted two-fold in a 96-well microplate. Then, $100 \mu \mathrm{L}$ of fresh inoculum $\left(1.5 \times 10^{6}\right.$ colony-forming units $\left./ \mathrm{mL}\right)$ prepared in MHB was added. The plates were covered with a sterile plate sealer, homogenised and incubated at $37^{\circ} \mathrm{C}$ for $18 \mathrm{~h}$. The concentration of DMSO used did not affect microbial growth. Wells containing MHB, $100 \mu \mathrm{L}$ of inoculum and DMSO was used as a negative control (systematically added). Chloramphenicol was used as a reference antibiotic. MICs were measured after $18 \mathrm{~h}$ incubation at $37^{\circ} \mathrm{C}$, followed by addition of $40 \mu \mathrm{L}$ of 0.2 $\mathrm{mg} / \mathrm{mL}$ INT and incubation at $37^{\circ} \mathrm{C}$ for $30 \mathrm{~min}$. Viable bacteria reduced the yellow dye (INT) to pink. The MIC was defined as the lowest concentration of compound that prevented this change and exhibited complete inhibition of microbial growth. Samples were tested alone or in the presence of PABN at a final concentration of $20 \mathrm{mg} / \mathrm{L}$. All assays were carried out in triplicate and were repeated three times.

\section{Results}

\subsection{Studied compounds}

The different natural compounds investigated in the present study are shown in Fig.

1. The terpenoids included four diterpenoids (hardwickiic acid and crotozambefurans A-C) and three pentacyclic triterpenoids (3-friedelanone, betulinic acid and oleanolic acid). Two alkaloids (norcassaide and norerythrosuaveolide) were tested. Phenolic compounds, including four coumarins, five xanthones, nine quinones and seven flavonoids, were also investigated. The compounds were tested for their ability to prevent the growth of MDR and reference strains of Gram-negative bacteria, alone and in the presence of the EPI PA $\beta N$. The results are summarised in Table 2. 


\subsection{Activity of the terpenoids}

Both the diterpenoids and the triterpenoids exhibited very weak activities. Tested alone, none of them was active against any of the tested bacterial strains (Table 2). The presence of EPI conferred only a little activity to some of the compounds against AcrAB- or TolC-deleted strains.

\subsection{Activity of the alkaloids}

Norcassaide and norerythrosuaveolide showed a moderate and limited activity against the tested bacteria. An MIC value of $64 \mathrm{mg} / \mathrm{L}$ was obtained with norcassaide against E. coli AG100A, E. aerogenes EA294 and EA298 and the reference $P$. aeruginosa PA01 strain (Table 2). A corresponding value for norerythrosuaveolide of $32 \mathrm{mg} / \mathrm{L}$ was noted against E. coli AG100A. A significant decrease in MIC values was observed in the presence of the EPI PA $\beta N$.

\subsection{Activity of phenolics (coumarins, xanthones, quinines and flavonoids)}

Most of the coumarins presented a reduced and limited activity when tested alone. The best activity $(\mathrm{MIC}=32 \mathrm{mg} / \mathrm{L})$ was obtained with MAB3 against $E$. coli AG100A. Most of the xanthones were poorly active. Laurentixanthone B showed significant activity, with its antibacterial effects being observed on all investigated bacteria including MDR strains. The quinone plumbagin, the two chalcones (flavonoids) 4hydroxylonchocarpin and bartericin C, and MAB3 (coumarin) were found to be active against bacteria including MDR strains. MIC values $<10 \mathrm{mg} / \mathrm{L}$ were obtained for plumbagin against E. coli AG100A and AG100A $A_{\text {Tet. }}$ The activity of this compound was better than that of chloramphenicol (MIC $=32 \mathrm{mg} / \mathrm{L})$ against $A G 100 \mathrm{~A}_{\text {Tet. }} .4-$ 
Hydroxylonchocarpin and bartericin C showed interesting antimicrobial properties, but the two compounds had an MIC > $10 \mathrm{mg} / \mathrm{L}$ against the bacteria studied in this work.

\subsection{Role of efflux pumps in the susceptibility of tested bacteria: identification of} $P A B N$-sensitive efflux in addition to the AcrAB-TolC pump

To assess the involvement of efflux in the activity of the tested compounds, the compounds were combined with the well known EPI PA $\beta N$. The results are summarised in parentheses in Table 2. When tested alone none of the terpenoids were active against $K$. pneumoniae or $P$. aeruginosa (Table 2), whereas a reduced and limited activity was noted with crotozambefuran $\mathrm{B}$ and $\mathrm{C}$ against $E$. aerogenes EA294 and EA298. Despite this moderate activity, it is important to note that an antibacterial effect of the tested terpenoids was detected against the efflux-deleted strain E. coli AG100A, except for crotozambefuran A. However, the enhancing effect of the EPI was limited during combination with terpenoids. PA $\beta N$ significantly increased the activity of most of the tested phenolic compounds. For the coumarins, MICs $<10 \mathrm{mg} / \mathrm{L}$ were recorded with MAB3 against four $E$. coli strains and $E$. aerogenes EA298. Interestingly, PA $\beta N$ increased the activity of laurentixanthone $B$, and MIC values $<10 \mathrm{mg} / \mathrm{L}$ were noted for two E. coli strains (Table 2). Amongst the quinones, plumbagin (naphthoquinone), which was active against all studied bacteria when tested alone, showed a significant increase in activity in the presence of the EPI. MICs $<10 \mathrm{mg} / \mathrm{L}$ were obtained with studied bacteria including MDR and reference strains. Furthermore, this activity was quite similar to or better than that of chloramphenicol in several cases. It should also be noted that one of the most active flavonoids (4-hydroxylonchocarpin) also exhibited MIC values $<10 \mathrm{mg} / \mathrm{L}$ against 
several MDR bacteria (Table 2). It is important to note the effect of the EPI on the susceptibility of E. coli and E. aerogenes strains deleted of AcrAB and TolC components (Table 2). This suggests the involvement of PA $\beta N$-sensitive efflux in addition to the AcrAB-TolC efflux pump. When tested in the presence of the EPI, compounds were active in ca. 46\% (94/204), 54\% (37/68), 64\% (65/102) and 75\% $(127 / 170)$ of the cases against $E$. aerogenes, $P$. aeruginosa, K. pneumoniae and $E$. coli, respectively, whilst they were only active in $29 \%, 41 \%, 48 \%$ and $46 \%$ of the cases when tested alone.

\subsection{Structure-activity relationship study}

When exploring the structure-activity relationship, it can be noted that terpenoids (both diterpenoids and triterpenoids) are poor antimicrobial compounds. A careful examination of the activities of the two tested alkaloids (norcassaide and norerythrosuaveolide with a terpenoid-like ring) suggests that the presence of nitrogen in the structure may enhance the antimicrobial activity of terpenoids. Regarding the activity of coumarins, it could be noted that 7-methoxycoumarin is generally more active than 7-hydroxycoumarin against MDR Gram-negative bacteria. 1,5-Dihydroxyxanthone and 1,7-dihydroxyxanthone exhibited similar activities, indicating that the location of the hydroxyl group in the structure does not significantly modulate their activities. It is also important to note that a simple naphthoquinone (plumbagin) exhibited better activity compared with 4-hydroxylonchocarpin (flavonoid), laurentixanthone B (xanthone) and MAB3 (coumarin). From a molecular structure point of view, the natural products exhibiting the best antibacterial activities have the same pharmacophore (Fig. 2). As plumbagin is the minimal scaffold required to have significant antibacterial activity in the absence of an EPI, it could be 
suggested that this pharmacophore is involved in the antibacterial activity. Other functional groups and their position (Fig. 2), in addition top those of the pharmacophoric moiety, may affect the antibacterial properties and modulate the susceptibility of the molecule to bacterial resistance mechanisms.

In the presence of the EPI, MIC values $<10 \mathrm{mg} / \mathrm{L}$ were obtained in $2(12.5 \%), 5$ (31.3\%), 9 (56.3\%) and $16(100 \%)$ of the 16 tested bacteria, respectively, for laurentixanthone B, MAB3, 4-hydroxylonchocarpin and plumbagin (Table 2).

\section{Discussion}

Tripartite drug efflux pumps, mainly those clinically reported as AcrAB-TolC in Enterobacteriaceae or as MexAB-OprM in $P$. aeruginosa, play a key role in multidrug resistance of pathogenic Gram-negative bacteria $[4,6]$. PA $\beta N$ has been reported as a potent inhibitor of the resistance-nodulation-cell division (RND) efflux systems and is particularly active on AcrAB-TolC and MexAB-OprM [7,21]. To determine the involvement of efflux pumps, the concentration of PA $\beta N$ used in this study $(20 \mathrm{mg} / \mathrm{L})$ had no intrinsic effect on the bacteria as previously determined [19], i.e. no significant variation in the MIC of chloramphenicol was observed for AG100A (AcrAB-deleted derivative of AG100). In contrast, under these conditions a significant increase in the antibacterial activity of several compounds was noted, showing that a number of natural products are substrate of efflux pumps acting in resistant strains of $E$. coli, $E$. aerogenes, K. pneumoniae and $P$. aeruginosa. However, this was not the general case with terpenoids, indicating that either this class of secondary metabolites is not highly active or that RND efflux pumps are not the main mechanism of resistance involved against such compounds in these MDR bacteria. Terpenoids could also 
have some difficulties in passing through the bacterial membrane barrier. The enhancing effect of PA $\beta N$ observed against the studied MDR bacteria with various compounds such as laurentixanthone B, plumbagin, 4-hydroxylonchocarpin, bartericin $C$ and MAB3 suggests that $P A B N$-sensitive efflux could be a major means of resistance. Regarding the involvement of MDR bacteria in treatment failures and the re-emergence of infectious diseases [1,2,22], the activity of some compounds (in the presence of $\mathrm{PA} \beta \mathrm{N}$ ) could be considered very promising. Pseudomonas aeruginosa is an important nosocomial pathogen highly resistant to clinically used antibiotics, causing a wide spectrum of infections and leading to substantial morbidity and mortality [23]. MDR Enterobacteriaceae, including K. pneumoniae, E. aerogenes and E. coli, have also been classified as antimicrobial-resistant organisms of concern in healthcare facilities [22]. Therefore, laurentixanthone B, plumbagin and 4hydroxylonchocarpin could be attractive candidates for the development of a new antimicrobial family against MDR strains in combination with EPIs. The antimicrobial activities of bartericin $\mathrm{C}$ and crotozambefurans $\mathrm{A}-\mathrm{C}$ are being reported and the results of the present study provide a clear explanation of the low bacterial susceptibility previously observed for other compounds [12,24]. The studied compounds included terpenoids, phenolics and alkaloids. Within the phenolic compounds, some of them, such as laurentixanthone B, MAB3 and 4hydroxylonchocarpin, exhibited significant activity and contained the same pharmacophore as observed in plumbagin.

By analysing the role of efflux mechanisms in the antimicrobial activity of the various compounds, it can be observed that compounds were more active against the tested bacteria in the presence of an EPI. These data clearly draw attention to the 
involvement of efflux pumps AcrAB-TolC or MexAB-OprM $[7,10,19,25]$ in the resistance of Gram-negative bacteria to natural compounds. This study highlights the key role of efflux mechanisms against several phenolic and alkaloid compounds and, consequently, indicates that inhibition of such efflux pumps could significantly improve their antimicrobial potencies.

\section{Acknowledgments}

The authors are grateful to C.A. Elkins and L. Amaral for the gift of bacterial strains.

They would also like to thank A. Davin, A. Lieutaud, E. Goemaere, A. Molitor, H.M. Poumale and P. K. Lunga for their helpful advice and fruitful discussions.

\section{Funding}

'Agence universitaire de la Francophonie' (AUF) to VK and 'Université de la Méditerranée and Service de Santé des Armées'.

\section{Competing interests}

None declared.

\section{Ethical approval}

Not required. 


\section{References}

[1] Blot S, Depuydt P, Vandewoude K, De Bacquer D. Measuring the impact of multidrug resistance in nosocomial infection. Curr Opin Infect Dis 2007;20:391-6.

[2] Falagas ME, Bliziotis IA. Pandrug-resistant Gram-negative bacteria: the dawn of the post-antibiotic era? Int J Antimicrob Agents 2007;29:630-6.

[3] Chopra I, Schofield C, Everett M, O'Neill A, Miller K, Wilcox M, et al. Treatment of health-care-associated infections caused by Gram-negative bacteria: a consensus statement. Lancet Infect Dis 2008;8:133-9.

[4] Nikaido H. Multidrug resistance in bacteria. Annu Rev Biochem 2009;78:119-46.

[5] Alekshun MN, Levy SB. Molecular mechanisms of antibacterial multidrug resistance. Cell 2007;128:1037-50.

[6] Davin-Régli A, Bolla JM, James CE, Lavigne JP, Chevalier J, Garnotel E, et al. Membrane permeability and regulation of drug 'influx and efflux' in enterobacterial pathogens. Curr Drug Targets 2008;9:750-9.

[7] Pagès J-M, Amaral L. Mechanisms of drug efflux and strategies to combat them: challenging the efflux pump of Gram-negative bacteria. Biochim Biophys Acta 2008;1794:826-33.

[8] Stavri M, Piddock L, Gibbons S. Bacterial efflux pump inhibitors from natural sources. J Antimicrob Chemother 2007;59:1247-60.

[9] Fischbach MA, Walsh CT. Antibiotics for emerging pathogens. Science 2009;325:1089-93.

[10] Saleem M, Nazir M, Ali MS, Hussain H, Lee YS, Riaz N, et al. Antimicrobial natural products: an update on future antibiotic drug candidates. Nat Prod Rep $2010 ; 27: 238-54$. 
[11] Mbaveng AT, Ngameni B, Kuete V, Simo IK, Ambassa P, Roy R, et al. Antimicrobial activity of the crude extracts and five flavonoids from the twigs of Dorstenia barteri (Moraceae). J Ethnopharmacol 2008;116:483-9.

[12] Mbaveng AT, Kuete V, Nguemeving JR, Simo IK, Ambassa P, Roy R, et al. Antimicrobial activity of the extracts and compounds from Vismia guineensis (Guttiferae). Asian J Tradit Med 2008;3:211-23.

[13] Poumale PHM, Randrianasolo R, Rakotoarimanga JV, Raharisololalao A, Krebs HC, Tchouankeu JC, et al. Flavonoid glycosides and other constituents of Psorospermum androsaemifolium Baker (Clusiaceae). Chem Pharm Bull (Tokyo) 2008;56:1428-30.

[14] Viveiros M, Jesus A, Brito M, Leandro C, Martins M, Ordway D, et al. Inducement and reversal of tetracycline resistance in Escherichia coli K-12 and expression of proton gradient-dependent multidrug efflux pump genes. Antimicrob Agents Chemother 2005;49:3578-82.

[15] Elkins CA, Mullis LB. Substrate competition studies using whole-cell accumulation assays with the major tripartite multidrug efflux pumps of Escherichia coli. Antimicrob Agents Chemother 2007;51:923-9.

[16] Ghisalberti D, Masi M, Pagès J-M, Chevalier J. Chloramphenicol and expression of multidrug efflux pump in Enterobacter aerogenes. Biochem Biophys Res Commun 2005;328:1113-8.

[17] Pradel E, Pagès J-M. The AcrAB-TolC efflux pump contributes to multidrug resistance in the nosocomial pathogen Enterobacter aerogenes. Antimicrob Agents Chemother 2002;46:2640-4. 
[18] Chevalier J, Pagès J-M, Eyraud A, Malléa M. Membrane permeability modifications are involved in antibiotic resistance in Klebsiella pneumoniae. Biochem Biophys Res Commun 2000;274:496-9.

[19] Lorenzi V, Muselli A, Bernardini AF, Berti L, Pagès JM, Amaral L, et al. Geraniol restores antibiotic activities against multidrug-resistant isolates from Gram-negative species. Antimicrob Agents Chemother 2009;53:2209-11.

[20] Kuete V, Mbaveng TA, Tsafack M, Beng VP, Etoa FX, Nkengfack AE, et al. Antitumor, antioxidant and antimicrobial activities of Bersama engleriana (Melianthaceae). J Ethnopharmacol 2008;115:494-501.

[21] Lomovskaya O, Bostian KA. Practical applications and feasibility of efflux pump inhibitors in the clinic-a vision for applied use. Biochem Pharmacol 2006;71:910-8.

[22] Nicolle LE. Infection control programmes to contain antimicrobial resistance. Geneva: World Health Organization; 2001. WHO/CDS/CSR/DRS/2001.7. http://whqlibdoc.who.int/hq/2001/WHO_CDS_CSR_DRS_2001.7.pdf [accessed January 2009].

[23] Cardoso O, Alves AF, Leitão R. Surveillance of antimicrobial susceptibility of Pseudomonas aeruginosa clinical isolates from a central hospital in Portugal. $\mathrm{J}$ Antimicrob Chemother 2007;60:452-4.

[24] Kuete V, Tangmouo JG, Meyer JJ, Lall N. Diospyrone, crassiflorone and plumbagin: three antimycobacterial and antigonorrhoeal naphthoquinones from two Diospyros species. Int J Antimicrob Agents 2009;34:322-5.

[25] Papadopoulos CJ, Carson CF, Chang BJ, Riley TV. Role of the MexAB-OprM efflux pump of Pseudomonas aeruginosa in tolerance to tea tree (Melaleuca 
alternifolia) oil and its monoterpene components terpinen-4-ol, 1,8-cineole and $\alpha$ terpineol. Appl Environ Microbiol 2008;74:1932-5. 
Fig. 1. Chemical structures of the natural compounds tested.

Fig. 2. Representation of pharmacophoric groups detected in the tested compounds. 


\section{Table 1}

Bacterial strains and features

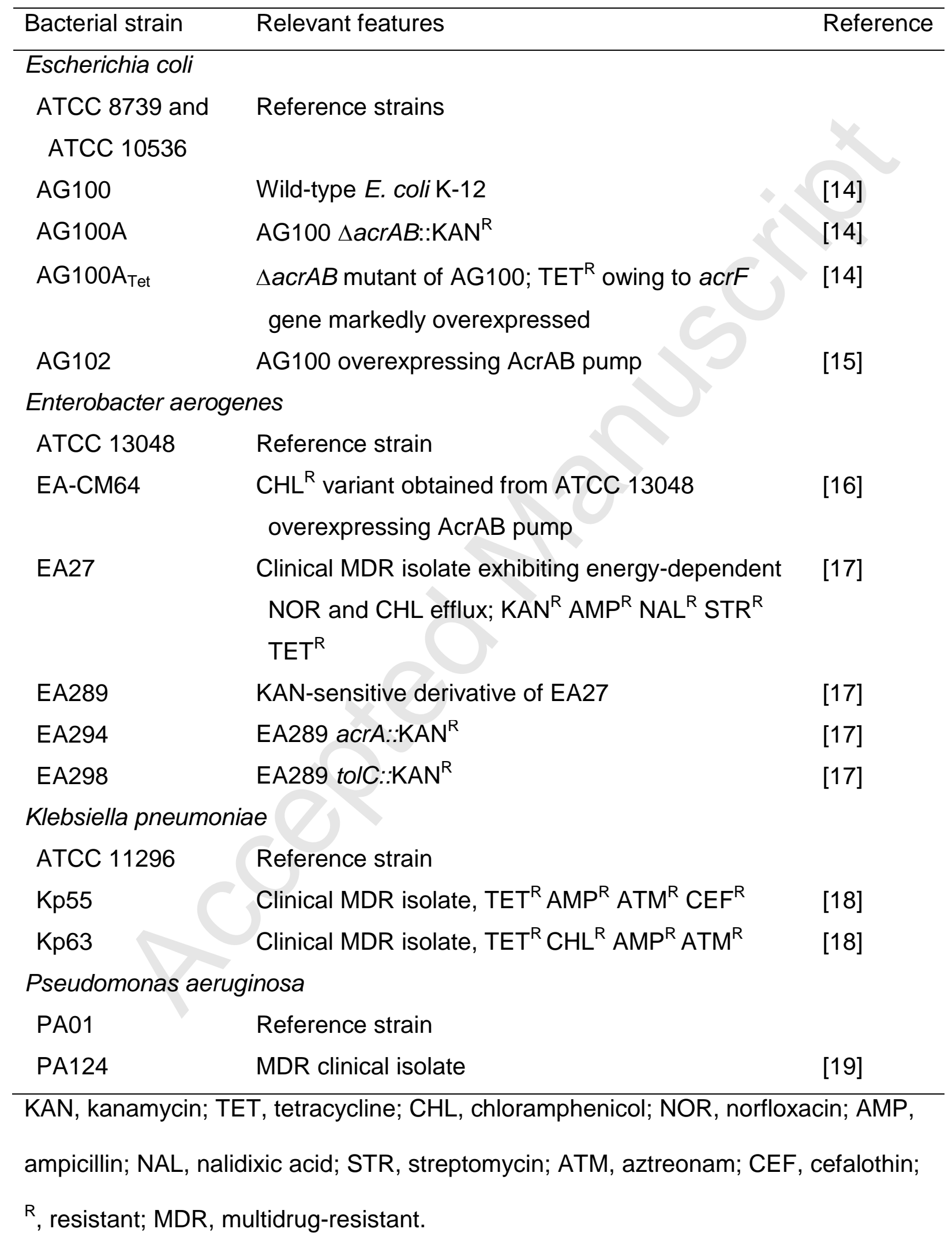


Table 2

Minimal inhibitory concentrations (MICs) of the studied components against the tested bacterial species

\begin{tabular}{|c|c|c|c|c|c|c|c|c|c|c|c|c|c|c|c|c|}
\hline \multirow[t]{4}{*}{ Sample } & \multicolumn{16}{|c|}{$\mathrm{MIC}(\mathrm{mg} / \mathrm{L})$ (with $20 \mathrm{mg} / \mathrm{L} \mathrm{PA} \mathrm{N}^{\mathrm{a}}$ ) } \\
\hline & \multicolumn{5}{|c|}{ Escherichia coli } & \multicolumn{6}{|c|}{ Enterobacter aerogenes } & \multicolumn{3}{|c|}{ Klebsiella pneumoniae } & \multicolumn{2}{|c|}{$\begin{array}{l}\text { Pseudomonas } \\
\text { aeruginosa }\end{array}$} \\
\hline & ATCC & AG100 & AG100A & $\mathrm{AG}_{100 \mathrm{~A}_{\text {Tet }}}$ & AG102 & ATCC & EA- & EA289 & EA294 & EA298 & EA27 & ATCC & Kp55 & Kp63 & PA01 & PA124 \\
\hline & 8739 & & & & & 13048 & CM64 & & & & & 11296 & & & & \\
\hline \multicolumn{17}{|l|}{ Terpenoids } \\
\hline Hardwickiic acid & $\mathrm{i}$ & $\mathrm{i}$ & i (16) & $\mathrm{i}$ & $\mathrm{i}$ & $\mathrm{i}$ & i & $\mathrm{i}$ & $\mathrm{i}$ & $\mathrm{i}$ & $\mathrm{i}$ & $\mathrm{i}$ & $\mathrm{i}$ & $\mathrm{i}$ & $\mathrm{i}$ & $\mathrm{i}$ \\
\hline Crotozambefuran A & $\mathrm{i}$ & $\mathrm{i}$ & $\mathrm{i}$ & $\mathrm{i}$ & $\mathrm{i}$ & $\mathrm{i}$ & $\mathrm{i}$ & $\mathrm{i}$ & $\mathrm{i}$ & $\mathrm{i}$ & $\mathrm{i}$ & $\mathrm{i}$ & $\mathrm{i}$ & $\mathrm{i}$ & $\mathrm{i}$ & $\mathrm{i}$ \\
\hline Crotozambefuran B & $\mathrm{i}$ & $\mathrm{i}$ & i (256) & $\mathrm{i}$ & $\mathrm{i}$ & i & $\mathrm{i}$ & $\mathrm{i}$ & $\mathrm{i}(128)$ & $\mathrm{i}(128)$ & $\mathrm{i}$ & $\mathrm{i}$ & $\mathrm{i}$ & $\mathrm{i}$ & $\mathrm{i}$ & $\mathrm{i}$ \\
\hline Crotozambefuran C & i (128) & $\mathrm{i}$ & $i(128)$ & $\mathrm{i}$ & $\mathrm{i}$ & i & $\mathrm{i}$ & $\mathrm{i}$ & $i(128)$ & $i(128)$ & $\mathrm{i}$ & $\mathrm{i}$ & $\mathrm{i}$ & $\mathrm{i}$ & $\mathrm{i}$ & $\mathrm{i}$ \\
\hline 3-Friedelanone & i & $\mathrm{i}$ & i (128) & $\mathrm{i}$ & $\mathrm{i}$ & $\mathrm{i}$ & $\mathrm{i}$ & $\mathrm{i}$ & $\mathrm{i}$ & $\mathrm{i}$ & $\mathrm{i}$ & $\mathrm{i}$ & $\mathrm{i}$ & $\mathrm{i}$ & $\mathrm{i}$ & $\mathrm{i}$ \\
\hline Betulinic acid & $\mathrm{i}$ & $\mathrm{i}$ & i (256) & $\mathrm{i}$ & $\mathrm{i}$ & $\mathrm{i}$ & $\mathrm{i}$ & $\mathrm{i}$ & $\mathrm{i}$ & $\mathrm{i}$ & $\mathrm{i}$ & $\mathrm{i}$ & $\mathrm{i}$ & $\mathrm{i}$ & $\mathrm{i}$ & $\mathrm{i}$ \\
\hline Oleanolic acid & i (128) & $\mathrm{i}$ & i (128) & $\mathrm{i}$ & i & $\mathrm{i}$ & $\mathrm{i}$ & $\mathrm{i}$ & i & $\mathrm{i}$ & i & i & $\mathrm{i}$ & i & i & $\mathrm{i}$ \\
\hline \multicolumn{17}{|l|}{ Coumarins } \\
\hline MAB3 & $\mathrm{i}(32)$ & $128(8)$ & $32(4)$ & $\mathrm{i}(8)$ & $i(8)$ & $256(64)$ & $\mathrm{i}$ & i (32) & i (16) & $\mathrm{i}(8)$ & $\mathrm{i}$ & $256(32)$ & i (16) & $\mathrm{i}(16)$ & i (128) & i (256) \\
\hline Mammeisin & $i(16)$ & i (32) & $\mathrm{i}(32)$ & $\mathrm{i}(32)$ & i (64) & $\mathrm{i}$ & $\mathrm{i}$ & $\mathrm{i}$ & $\mathrm{i}(128)$ & $\mathrm{i}(16)$ & $\mathrm{i}$ & i (64) & $\mathrm{i}(16)$ & $\mathrm{i}(128)$ & $\mathrm{i}$ & $\mathrm{i}$ \\
\hline 7-Hydroxycoumarin & $\mathrm{i}$ & $\mathrm{i}$ & $\begin{array}{l}256 \\
(128)\end{array}$ & $i(128)$ & $\mathrm{i}$ & $\mathrm{i}$ & $\mathrm{i}$ & $\mathrm{i}$ & $\begin{array}{l}256 \\
(64)\end{array}$ & $\begin{array}{l}256 \\
(32)\end{array}$ & $\mathrm{i}$ & $i(128)$ & $\mathrm{i}$ & $\mathrm{i}$ & $\mathrm{i}$ & i (256) \\
\hline 7-Methoxycoumarin & i (128) & $\begin{array}{l}256 \\
(128)\end{array}$ & $128(32)$ & $256(128)$ & $256(64)$ & i (128) & $\begin{array}{l}128 \\
(32)\end{array}$ & $\mathrm{i}$ & $\begin{array}{l}128 \\
(32)\end{array}$ & $\begin{array}{l}128 \\
(16)\end{array}$ & $\begin{array}{l}256 \\
(64)\end{array}$ & $256(64)$ & i (128) & $i(128)$ & $\begin{array}{l}256 \\
(128)\end{array}$ & $256(64)$ \\
\hline \multicolumn{17}{|l|}{ Xanthones } \\
\hline 1,5-Dihydroxyxanthone & $i(16)$ & i (128) & $i(16)$ & $\mathrm{i}(16)$ & $256(32)$ & $256(128)$ & $\mathrm{i}$ & $\mathrm{i}$ & $128(8)$ & $256(8)$ & $\mathrm{i}$ & $256(32)$ & i (32) & i (32) & i (256) & $\begin{array}{l}256 \\
(128)\end{array}$ \\
\hline 1,7-Dihydroxyxanthone & i (32) & i (32) & i (16) & i (32) & i (32) & i (256) & $\mathrm{i}$ & $\mathrm{i}$ & $64(4)$ & $128(4)$ & $\mathrm{i}$ & $256(64)$ & i (32) & i (32) & i (128) & i (128) \\
\hline Laurentixanthone B & $128(8)$ & $256(32)$ & $32(8)$ & $256(16)$ & $256(32)$ & $256(16)$ & $\begin{array}{l}256 \\
(32)\end{array}$ & $\begin{array}{l}128 \\
(64)\end{array}$ & $\begin{array}{l}256 \\
(32)\end{array}$ & $\begin{array}{l}256 \\
(32)\end{array}$ & $\begin{array}{l}256 \\
(16)\end{array}$ & $64(32)$ & $\begin{array}{l}256 \\
(64)\end{array}$ & $\begin{array}{l}256 \\
(16)\end{array}$ & $256(64)$ & $256(16)$ \\
\hline Smeathxanthone A & $\mathrm{i}$ & $\mathrm{i}$ & $\begin{array}{l}256 \\
(256)\end{array}$ & $\mathrm{i}$ & $\begin{array}{l}256 \\
(256)\end{array}$ & $\mathrm{i}$ & i & i & i & $\mathrm{i}$ & i & $\mathrm{i}$ & $\mathrm{i}$ & i & $\mathrm{i}$ & $\mathrm{i}$ \\
\hline Smeathxanthone B & $\mathrm{i}$ & $\mathrm{i}$ & $\begin{array}{l}256 \\
(256)\end{array}$ & $\mathrm{i}$ & $\begin{array}{l}256 \\
(256)\end{array}$ & $\mathrm{i}$ & $\mathrm{i}$ & i (128) & $\mathrm{i}$ & $\mathrm{i}$ & $\mathrm{i}$ & $\mathrm{i}$ & $\mathrm{i}$ & $\mathrm{i}$ & $\mathrm{i}$ & $\mathrm{i}$ \\
\hline Quinones & & & & & & & & & & & & & & & & \\
\hline
\end{tabular}




\begin{tabular}{|c|c|c|c|c|c|c|c|c|c|c|c|c|c|c|c|c|}
\hline Plumbagin & $16(2)$ & $32(1)$ & $2(0.12)$ & $8(0.25)$ & $16(0.5)$ & $16(4)$ & $64(8)$ & $32(4)$ & $16(2)$ & $16(2)$ & $32(4)$ & $16(1)$ & $32(4)$ & $32(4)$ & $16(1)$ & $32(0.5)$ \\
\hline Lapachol & $128(32)$ & $256(64)$ & $64(16)$ & $\mathrm{i}(64)$ & $i(64)$ & $128(32)$ & $\mathrm{i}$ & $\mathrm{i}$ & $i(128)$ & i (128) & $\mathrm{i}$ & $256(128)$ & i (256) & i (256) & $256(32)$ & $i(64)$ \\
\hline 2-Acetylfuro-1,4-naphthoquinone & $256(64)$ & i (64) & $128(32)$ & i (128) & i (256) & i (256) & $\mathrm{i}$ & $\mathrm{i}$ & $\mathrm{i}$ & i (256) & $\mathrm{i}$ & i (256) & $\mathrm{i}$ & $\mathrm{i}$ & $\begin{array}{l}256 \\
(256)\end{array}$ & $\mathrm{i}$ \\
\hline Newbouldiaquinone & $128(16)$ & $256(32)$ & $32(16)$ & $128(32)$ & $256(64)$ & $64(32)$ & i (128) & $\begin{array}{l}256 \\
(64)\end{array}$ & $\begin{array}{l}128 \\
(32)\end{array}$ & $\begin{array}{l}256 \\
(32)\end{array}$ & i (256) & $64(16)$ & $\begin{array}{l}256 \\
(64)\end{array}$ & $\begin{array}{l}256 \\
(64)\end{array}$ & $128(16)$ & $256(16)$ \\
\hline Newbouldiaquinone $\mathrm{A}$ & $64(16)$ & $128(32)$ & $64(32)$ & $256(32)$ & $256(64)$ & $128(16)$ & $\begin{array}{l}256 \\
(128)\end{array}$ & $\begin{array}{l}128 \\
(128)\end{array}$ & $\begin{array}{l}128 \\
(64)\end{array}$ & $\begin{array}{l}256 \\
(32)\end{array}$ & $\mathrm{i}$ & $64(32)$ & $\begin{array}{l}128 \\
(32)\end{array}$ & $\begin{array}{l}128 \\
(64)\end{array}$ & $128(16)$ & $128(32)$ \\
\hline Vismiaquinone & $\mathrm{i}$ & $\mathrm{i}$ & i (128) & $\mathrm{i}$ & $\mathrm{i}$ & $\mathrm{i}$ & & $\mathrm{i}$ & $\mathrm{i}$ & $\mathrm{i}$ & $\mathrm{i}$ & $256(256)$ & $\begin{array}{l}256 \\
(256)\end{array}$ & $\begin{array}{l}128 \\
(128)\end{array}$ & $\mathrm{i}$ & $\mathrm{i}$ \\
\hline Vismiaquinone $\mathrm{C}$ & $\begin{array}{l}128 \\
(128)\end{array}$ & $\begin{array}{l}256 \\
(128)\end{array}$ & $64(4)$ & $256(128)$ & $\begin{array}{l}256 \\
(256)\end{array}$ & $\mathrm{i}$ & i & $\begin{array}{l}256 \\
(128)\end{array}$ & $\begin{array}{l}128 \\
(32)\end{array}$ & $\begin{array}{l}256 \\
(64)\end{array}$ & $\mathrm{i}$ & $256(256)$ & $64(64)$ & $64(64)$ & i & i (256) \\
\hline $\begin{array}{l}\text { 3-Geranyloxy-6-methyl-1,8- } \\
\text { dihydroxyanthraquinone }\end{array}$ & $\mathrm{N} / \mathrm{T}$ & $\mathrm{N} / \mathrm{T}$ & $\mathrm{N} / \mathrm{T}$ & $\mathrm{N} / \mathrm{T}$ & $\mathrm{N} / \mathrm{T}$ & i & i (128) & $\mathrm{i}(128)$ & i (64) & $i(64)$ & i (256) & $256(256)$ & $\begin{array}{l}128 \\
(128)\end{array}$ & $\begin{array}{l}256 \\
(64)\end{array}$ & $\mathrm{i}$ & $\mathrm{i}$ \\
\hline Bivismiaquinone & $\mathrm{i}$ & $\mathrm{i}$ & $\mathrm{i}$ & $\mathrm{i}$ & & i & $\mathrm{i}$ & $\mathrm{i}$ & $\mathrm{i}$ & $\mathrm{i}$ & $\mathrm{i}$ & $\mathrm{i}$ & $\mathrm{i}$ & $\begin{array}{l}256 \\
(256)\end{array}$ & $\mathrm{i}$ & $\mathrm{i}$ \\
\hline Flavonoids & & & & & & & & & & & & & & & & \\
\hline Quercetin & $\begin{array}{l}256 \\
(256)\end{array}$ & $\mathrm{i}$ & i (256) & $256(256)$ & $\mathrm{i}$ & $\mathrm{i}$ & $\mathrm{i}$ & $\mathrm{i}$ & $\mathrm{i}$ & i (128) & $\mathrm{i}$ & $256(256)$ & $\begin{array}{l}256 \\
(256)\end{array}$ & $\begin{array}{l}256 \\
(256)\end{array}$ & $\begin{array}{l}256 \\
(256)\end{array}$ & $\mathrm{i}$ \\
\hline Kaempferol & $\begin{array}{l}256 \\
(256)\end{array}$ & $\mathrm{i}$ & $128(64)$ & $256(256)$ & $\mathrm{i}$ & $256(256)$ & $\mathrm{i}$ & $\mathrm{i}$ & i (256) & i (128) & $\mathrm{i}$ & $256(256)$ & $\begin{array}{l}256 \\
(128)\end{array}$ & $\begin{array}{l}256 \\
(256)\end{array}$ & $\begin{array}{l}256 \\
(256)\end{array}$ & $\mathrm{i}$ \\
\hline Gancaonin Q & $\mathrm{i}$ & $\mathrm{i}$ & $\begin{array}{l}256 \\
(128)\end{array}$ & i & $\mathrm{i}$ & $\mathrm{i}$ & $\mathrm{i}$ & $\mathrm{i}$ & $\mathrm{i}$ & $\mathrm{i}$ & $\mathrm{i}$ & $256(256)$ & $\mathrm{i}$ & $\mathrm{i}$ & $\begin{array}{l}256 \\
(256)\end{array}$ & $\begin{array}{l}256 \\
(256)\end{array}$ \\
\hline Stipulin & $128(64)$ & i (128) & $64(32)$ & i (256) & $\mathrm{i}(256)$ & $256(64)$ & $\mathrm{i}$ & $\mathrm{i}$ & $\mathrm{i}$ & i (256) & $\mathrm{i}$ & $128(64)$ & $\mathrm{i}$ & $\mathrm{i}$ & $\mathrm{i}(256)$ & $\begin{array}{l}256 \\
(128)\end{array}$ \\
\hline Angusticornin B & $128(32)$ & $256(64)$ & $64(16)$ & $256(64)$ & $i(64)$ & 256 (128) & i (128) & i (256) & i (256) & i (256) & $\mathrm{i}$ & $128(64)$ & $\mathrm{i}(256)$ & $\begin{array}{l}256 \\
(64)\end{array}$ & $128(64)$ & $128(32)$ \\
\hline 4-Hydroxylonchocarpin & $128(4)$ & $128(8)$ & $32(4)$ & $128(8)$ & $256(32)$ & $256(4)$ & $\begin{array}{l}256 \\
(64)\end{array}$ & $128(8)$ & $256(8)$ & $256(8)$ & $256(8)$ & $64(16)$ & $\begin{array}{l}256 \\
(32)\end{array}$ & $\begin{array}{l}256 \\
(32)\end{array}$ & $128(32)$ & $256(8)$ \\
\hline Bartericin C & $64(8)$ & $128(16)$ & $32(4)$ & $64(16)$ & $128(32)$ & $128(128)$ & $\begin{array}{l}256 \\
(256)\end{array}$ & $\begin{array}{r}128 \\
(16)\end{array}$ & $\begin{array}{r}128 \\
(16)\end{array}$ & $\begin{array}{r}128 \\
(16)\end{array}$ & $\begin{array}{l}256 \\
\quad(256)\end{array}$ & $128(128)$ & $\begin{array}{l}128 \\
(128)\end{array}$ & $\begin{array}{l}128 \\
(128)\end{array}$ & $\begin{array}{l}128 \\
(128)\end{array}$ & $\begin{array}{l}256 \\
(256)\end{array}$ \\
\hline \multicolumn{17}{|l|}{ Alkaloids } \\
\hline Norcassaide & $128(32)$ & $256(64)$ & $64(8)$ & $128(16)$ & $256(16)$ & $256(64)$ & i (128) & $\begin{array}{l}256 \\
\quad(128)\end{array}$ & $64(32)$ & $64(16)$ & i (128) & $128(16)$ & $\begin{array}{l}256 \\
\quad(32)\end{array}$ & $\begin{array}{l}128 \\
(32)\end{array}$ & $64(8)$ & $128(32)$ \\
\hline
\end{tabular}




\begin{tabular}{|c|c|c|c|c|c|c|c|c|c|c|c|c|c|c|c|c|}
\hline Norerythrosuaveolide & $128(16)$ & $128(32)$ & $32(8)$ & $128(16)$ & $128(16)$ & $128(32)$ & $\mathrm{i}(64)$ & $\begin{array}{c}256 \\
(64)\end{array}$ & $\begin{array}{r}128 \\
(64)\end{array}$ & $\begin{array}{r}128 \\
(32)\end{array}$ & $\begin{array}{l}256 \\
(64)\end{array}$ & $128(32)$ & $\begin{array}{l}256 \\
(128)\end{array}$ & $\begin{array}{l}128 \\
(128)\end{array}$ & $128(32)$ & $128(32)$ \\
\hline Chloramphenicol (reference antibiotic) & $4(1)$ & $4(0.5)$ & $\begin{array}{l}0.5 \\
\quad(0.25)\end{array}$ & $32(4)$ & $32(2)$ & $4(1)$ & $256(8)$ & i (128) & $64(16)$ & $64(16)$ & i (128) & $4(1)$ & $32(4)$ & i (128) & $128(8)$ & $256(8)$ \\
\hline
\end{tabular}

$\mathrm{PA} \beta \mathrm{N}$, phenylalanine arginine $\beta$-naphthylamide; $\mathrm{N} / \mathrm{T}$, not tested.

a The MIC of PAßN was $64 \mathrm{mg} / \mathrm{L}$ for AG100A and $>256 \mathrm{mg} / \mathrm{L}$ for other E. coli, E. aerogenes, K. pneumoniae and $P$. aerogenes strains. i, sample not active up to $256 \mathrm{mg} / \mathrm{L}$. 


\section{Terpenoids}
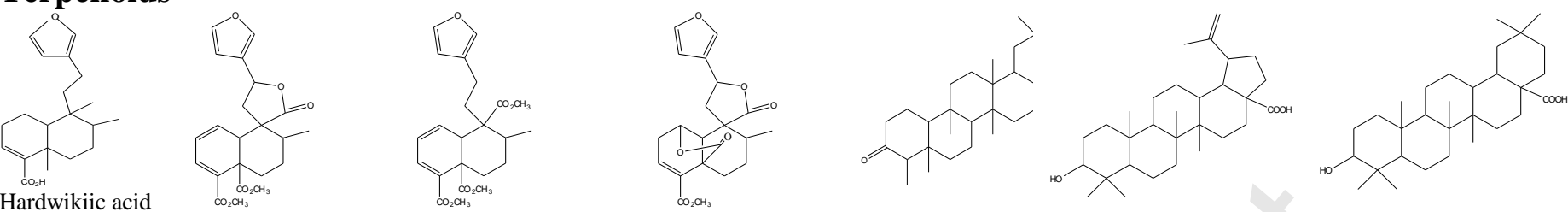

Crotozambefuran A Crotozambefuran B

Crotozambefuran

3-Friedelanone

Betulinic acid

Oleanolic acid

\section{Coumarins}
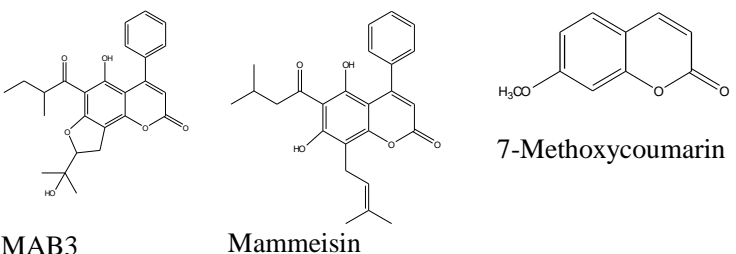

7-Methoxycoumarin

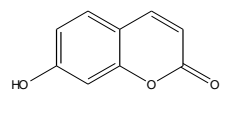

7-Hydroxycoumarin

Alkaloids

MAB3

Mammeisin

\section{Xanthones}<smiles>O=c1c2cccc(Cl)c2oc2cccc(O)c12</smiles>

$1,5-$

Dihydroxyxanthone

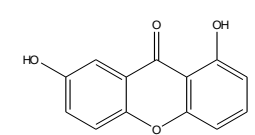

1,7-Dihydroxyxanthone

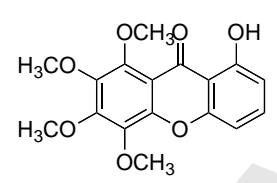

Laurentixanthone B

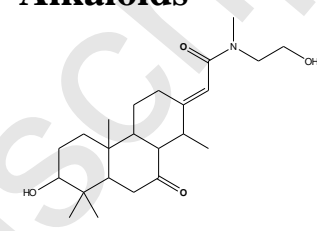

Norcassaide

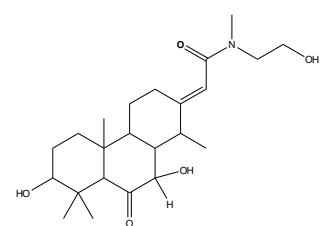

Norerythrosuaveolide

Naphthoquinones and anthraquinones<smiles>CC1=CC(=O)c2c(O)cccc2C1=O</smiles>

Plumbagin<smiles>CC(C)=CCc1ccc(O)c(O)c1OCC(C)C</smiles>

Vismiaquinone $\mathrm{C}$

3-Geranyloxy-6

methyl-1,8-

dihydroxyanthraqui

none

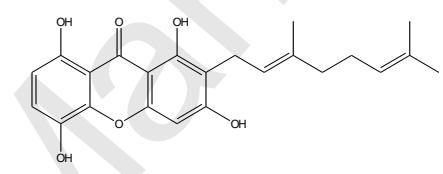

Smeathxanthone A

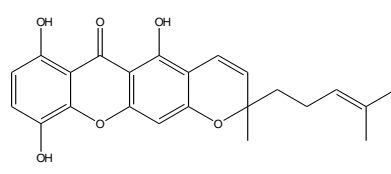

Smeathxanthone B<smiles>C=CC1=C(CC=C(C)C)C(=O)c2ccccc2C1=O</smiles>

naphthoquinone

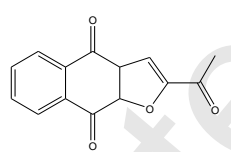

2-Acetylfuro-1,4-

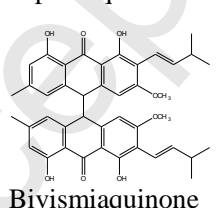

Bivismiaquinone

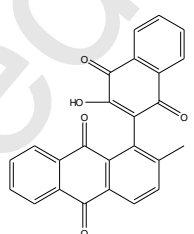

Newbouldiaquinone

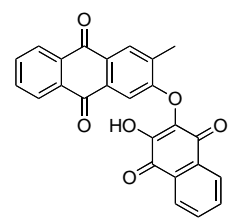

Newbouldiaquinone A

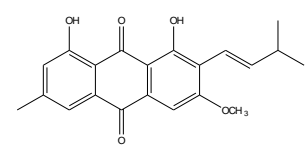

Vismiaquinone

\section{Flavonoids}<smiles>O=C1CCCCC1C1CCCC1C1CCCC1</smiles>

Quercetin

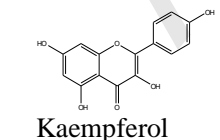

Kaempferol

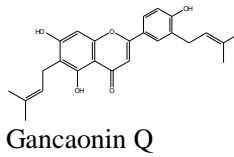<smiles>CC(C)CCC1CC(C)CC(CCC2CC(C)CC2CC(C)C)C1[13CH]</smiles>
Stipulin

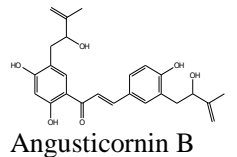<smiles>O=C(/C=C/c1ccc(O)cc1)c1ccc2c(c1O)C=CC1CCCC2C1</smiles>

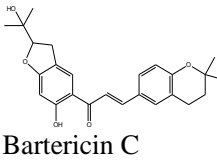


<smiles>CC1=CC(=O)c2c(O)cccc2C1=O</smiles>

Plumbagin<smiles>CC1(C)C=Cc2c(ccc(C(=O)/C=C/c3ccc(O)cc3)c2O)O1</smiles>

4-Hydroxylonchocarpin<smiles>COC1c2oc3cccc(O)c3c(=O)c2C(O)C(O)C1O</smiles>

Laurentixanthone B<smiles>CCC(C)C(=O)c1c(O)c2c(c3c1OC(C(C)(C)O)C3)OC(=O)CC2c1ccccc1</smiles>

MAB3

-Pharmacophore 